\title{
LITERATURE REVIEW OF LEAN MANUFACTURING IN SMALL AND MEDIUM- SIZED ENTERPRISES
}

\author{
Laila Driouach $^{1^{*}}$, Khalid Zarbane ${ }^{1}$, Zitouni Beidouri ${ }^{1}$ \\ ${ }^{1}$ Laboratory of Mechanics, Production and Industrial Engineering, Hassan II University, Casablanca \\ 20999, Morocco
}

(Received: December 2018 / Revised: May 2019 / Accepted: August 2019)

\begin{abstract}
Small and medium-sized enterprises (SMEs) represent an important component of the economy in both developed and developing countries. Nowadays, the competitive industrial environment is encouraging these companies to redesign their manufacturing practices. Lean manufacturing (LM) has been widely implemented in several industries and has been shown to have had a positive impact on the performance and development of companies. This review aims to examine this impact on the performance of manufacturing companies, to emphasize the recent progress of LM amongst SMEs worldwide, and to show that most successful LM initiatives are those implemented in SMEs and large companies. However, very small businesses (VSBs) are struggling to introduce LM into their management systems. A new approach has been developed to establish a new lean implementation framework that could be adapted to the specific context of VSBs.
\end{abstract}

Keywords: Benefits; Lean implementation; Lean manufacturing; SMEs; Very small businesses

\section{INTRODUCTION}

Small and medium-sized enterprises (SMEs) play a major role in international economies and represent a vital component of economic growth in emerging ones. Therefore, SMEs are considered as one of the main contributors to GDP and employment worldwide (Saleh \& Ndubisi, 2006).

In Europe, SMEs employ 93 million people and generate $57 \%$ of the added value. Most SMEs (93\%) are micro businessed employing fewer than ten employees (Muller et al., 2017). In Morocco, according to Moroccan Confederation of SME statistics, SMEs represent $95 \%$ of the the economic fabric. Indeed, they are considered to be a vital source of wealth and job creation, constituting $40 \%$ of production and $31 \%$ of exports (CDVM, 2011). However, SMEs are presently struggling to maintain their competitiveness due to the high competition in the economic context. Therefore, they are concentrating on focusing their efforts on reducing costs and producing more customized products, in smaller batch sizes and with a short lead time. LM practices and techniques could help improve the performance of manufacturing companies, as well as reducing their costs.

LM is a set of techniques that aims to increase the creation of value and reduce all types of waste. The process was developed by Taiichi Ohno during the creation of the Toyota production system (TPS) in the 1950s (Rauch et al., 2017).

\footnotetext{
*Corresponding author's email: laila.driouach@gmail.com, Tel.0607342564
}

Permalink/DOI: https://dx.doi.org/10.14716/ijtech.v10i5.2718 
Many companies in different fields all over the world have launched initiatives and projects to introduce Lean practices (Narayanamurthy et al., 2018; Bajjou \& Chafi, 2018a; Bajjou \& Chafi, 2018b). Typical lean methods have been applied for many years in order to structure lean production process in certain multinational companies; initially specialized ones in the automotive industry, but later ones in other industrial sectors, including smaller companies (Rauch et al., 2017).

According to previous research based on different contexts, SMEs have also successfully introduced Lean practices in Europe (Ulewicz \& Kucęba, 2016; Antosz \& Stadnicka, 2017); in Malaysia (Rose et al., 2017); Brazil (Ferreira et al., 2016); India (Verma \& Sharma, 2017; Gandhi et al., 2018); Morocco (Fakkous et al., 2015; Belhadi at al., 2016; Bajjou \& Chafi, 2018c), and Italy (Matt \& Rauch, 2013; Rauch et al., 2017), amongs to the countries.

This review paper aims to highlight the positive impact of Lean on company performance, as reflected in operational, strategic, administrative and human aspects. The paper also indicates that LM has proved its efficiency in performance improvement in large companies, as well as SMEs. In order to develop a new Lean strategy which could be suitable for very small businesses (VSBs), we suggest an approach to the design of a new framework for Lean implementation adapted to small company characteristics.

\section{RESEARCH METHODOLOGY}

The Lean philosophy was developed at the beginning of the automotive industry. Nowadays, it is starting to be more integrated into different fields (for example, the construction, health and manufacturing industries, and administration) and is considered as a new way of designing management systems in order to improve process efficiency (Garre et al., 2017; Bajjou \& Chafi, 2018d; Bajjou et al., 2019).

This review is based on a detailed literature review analysis. The research was conducted by combining two groups of key words, as presented in Table 1. The review combines all relevant articles published after 1990, the year of publication of Womack et al.'s famous book "The Machine that Changed the World" (Womack et al., 1990). This book played a major role in the spread of LM around the world.

Table1 Documentary research details

\begin{tabular}{clll}
\hline Period & Database used & Key words group 1 & Key words group 2 \\
\hline \multirow{4}{*}{$1990-2019$} & Google scholar & - Lean & - SME \\
& Science direct & - Lean manufacturing & - Small businesses \\
& Springer link & - Lean benefits & \\
& Elsevier & - Lean frameworks & \\
& & - Lean implementation & \\
\hline
\end{tabular}

As shown in Figure 1, the methodological approach of the paper consists of synthesizing the literature, identifying research gaps and recommending new research areas.

\section{LEAN MANUFACTURING: MAIN CONCEPTS}

Lean manufacturing is a production system originally developed by Toyota in Japan in the 1950s, and to date continues to make the group more successful. It is also called "Lean Management" (Drew et al., 2004) and was a concept well known in the United States in the 1980s (Liker., 2004).

The literature shows different definitions of Lean that vary depending on the interpretation of certain authors and companies (Liker., 2004; Womack \& Jones., 2005). 
Search online databases; selection of reputed referred journals, theses and surveys reports...

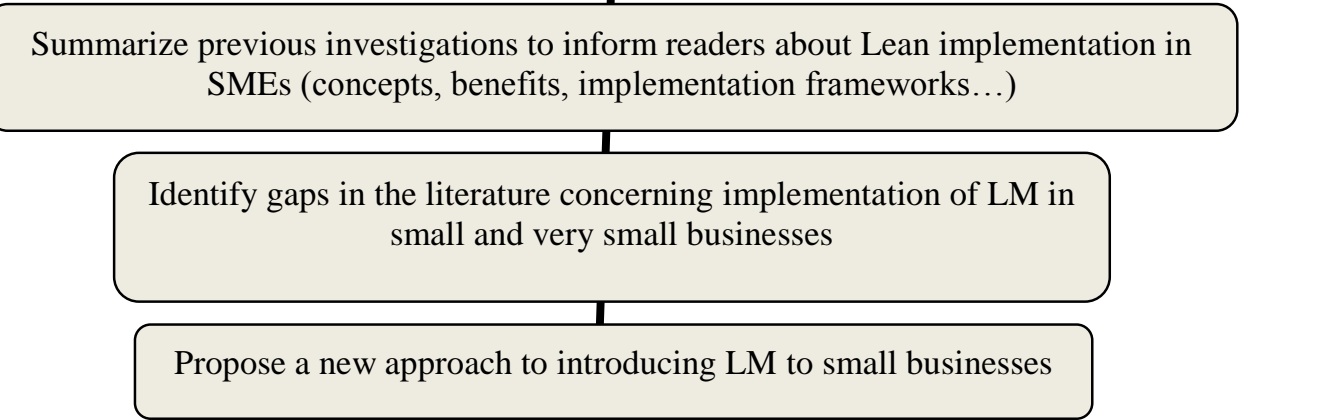

Figure 1 Research methodology flowchart

According to Drew et al. (2004) "Lean is a whole integrating many principles, tools and techniques whose aim is reducing all sources of value chains inefficiencies and meanwhile bridging the gaps between actual performance and customer requirements". Lyonnet (2010) defines Lean according to six main concepts:

1) Waste elimination: to create effective value, it is necessary to identify waste and to eliminate any action that does not create value for customers. Therefore, eight forms of waste were identified (MUDA in Japanese): overproduction, waiting times, useless transportation, steps without added value (over-processing), excessive inventories, unnecessary human movements, defective part production (quality defects) and under-utilization of human potential.

2) The just-in-time operating mode involves "bringing the right part to the right place at the right time with the right amount".

3) Quality: industry aims to develop the best methods in order to improve quality, ranging from the Quality Control concept to Total Quality Management. The main goal of promoting perfect quality is to provide a product that meets customers' expectations (Lyonnet, 2010).

4) Continuous improvement (Kaizen in japanese): it is a process based on a set of efficient actions, productivity, processes... Kaizen is a state of spirit and a work culture, but above all a management practice, using tools and resources. Kaizen generally includes methods such as 5S, Kanban, SMED, TPM.

5) Visual management reveals the state of production; it consists of using visual means such as billboards on which a set of indicators are published. The 5S method, Kanban, and Andon systems are the main visual management techniques.

Employee management gathers all the principles of team work, multifunctional teams, versatility and staff involvement.

\section{LEAN APPROACH IMPACTS ON INDUSTRIAL PERFORMANCE}

Lean manufacturing aims to improve the whole system, to optimize costs, quality and delivery time, and to improve staff safety (Drew et al., 2004). These benefits have been classified into three main categories: operational, administrative and strategic (Kilpatrick, 2003).

\subsection{Operational Benefits}

The main operational benefits include an $80 \%$ reduction in stock (Kilpatrick, 2003); a $70 \%$ to 90\% reduction in quality defects (Prakash \& Prasad, 2014); and an average increase of 50\% in productivity, which consequently reduces manufacturing costs (Kilpatrick, 2003; Demeter \& Matyusz, 2011). Moreover, several operational impacts have been reported, such as a reduction 
in cycle time of $90 \%$ (Kilpatrick, 2003; Demeter \& Matyusz, 2011); improvements in stock rotation (Demeter \& Matyusz, 2011); a reduction in occupied spaces of 75\% (Kilpatrick, 2003); and a reduction in change over times of up to $70 \%$.

- Reductions in cycle time/lead time/delivery time: "lead time", or crossing time, is the time which elapses between the beginning of a process and its end. It is a usual indicator of Lean. Cycle time refers to the time interval separating two similar consecutive entities or events in the same process. Therefore, eradicating waste effectively reduces both lead-time and cycle time (by 90\%) (Kilpatrick, 2003), which influences delivery time positively.

- Reduction in production costs: as a result of the reduction in production time, the operating costs incurred by the use of various resources (energy, wages, working time etc) will also be significantly reduced. LM is considered as a cost-cutting mechanism and a guideline for creatinga world-class organization (if implemented properly).

- Stock reduction/space reduction: LM aims to optimize the use of all production resources for the company. In fact, LM tools allow stock reduction, human resource optimization, and a reduction of occupied spaces of $75 \%$ (Kilpatrick, 2003).

- Increased productivity/quality: LM improves productivity and product quality through system-wide changes, including manufacturing processes and work efficiency. Several research studies have reported that Lean practice implementation leads to an increase of 70-90\% in quality (Prakash \& Prasad, 2014) and 50\% in productivity (Kilpatrick, 2003).

These benefits have been observed in both large enterprises (LEs) and small and medium-sized ones (SMEs) operating in many sectors of activity, including services (Kilpatrick, 2003; Demeter \& Matyusz, 2011).

\subsection{Administrative and Strategic Benefits}

Most organizations have implemented Lean to improve operational indicators; however, its administrative and strategic benefits are also impressive (Kilpatrick, 2003). In terms of the administrative benefits of LM, these mainly include:

- Simplicity of administrative processes.

- Reduction in control errors (Kilpatrick, 2003).

- Providing customers with better service quality.

- $25 \%$ increase in customer order accuracy in terms of quality and delivery.

- Reduction in turn-over and resulting attrition costs.

- Reduction in administrative costs.

As for strategic benefits, these relate to an increase in sales volume (20\%) and in revenues by almost $40 \%$ for companies that have implemented the Lean approach (Kilpatrick, 2003). Improvements in service level have also been highlighted following LM deployment within French SMEs (Baglin \& Capraro, 1999).

\subsection{Lean impacts on staff}

LM benefits do not only cover operational, strategic and administrative performance. Human resources are among the vital pillars of LM success within an organization (Drew et al., 2004), and many research studies have identified positive impacts of the Lean system on staff. LM implementation contributes to improving employee motivation (Baglin \& Capraro, 1999; Treville \& Antonakis, 2006), developing new skills, fostering versatility, improving working conditions (Saurin \& Ferreira, 2009) and enhancing staff skills through solving problems and training (Treville \& Antonakis, 2006).

Other studies have revealed that Lean can reduce stress and make employees happy. Therefore, the Lean system influences the whole business because of its various positive impacts. It can help 
ensure the whole company is committed to continuous improvement and is focused on customer expectations. Moreover, the Lean approach helps to improve employee relationships with management, and encourages teamwork based on effective productivity, rigor, discipline, and organization.

Figure 2 summarizes most of the positive Lean impacts on staff mentioned in the literature, together with the operational, strategic and administrative benefits that contribute to improving enterprises performance.

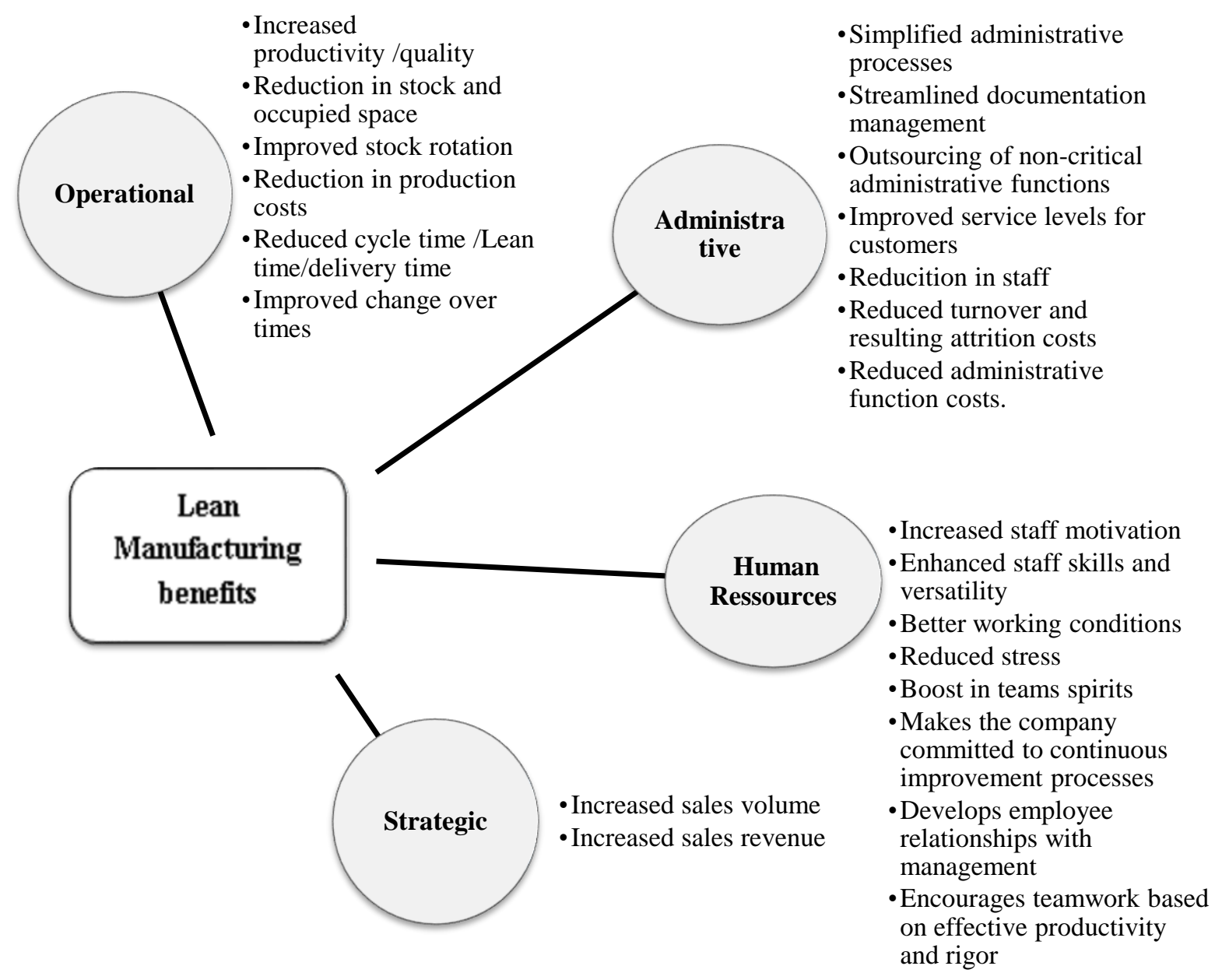

Figure 2 Lean manufacturing contribution to boosting performance

\section{LEAN MANUFACTURING IN SMES}

SMEs are the backbone of economies. Therefore, to survive in a very competitive environment, these companies need to improve their current systems and meet customer needs. Lean manufacturing is one of the best management practices for all industries. In Europe, SMEs makea strong contribution in terms of enhancing efficiency and improving productivity (Bakås et al., 2011). This provides the basis for the European Commission to support the Innovative Productivity project in European Regions (ERIP). The project comprises six partner countries (Norway, Belgium, Sweden, Germany, Netherlands and United Kingdom). A common methodology for implementing Lean manufacturing practices has been developed by the ERIP partners and tested in participating SMEs (from each country, 4-7 small and medium-sized enterprises were selected) (Bakås et al., 2011). 
The industrial sector in Greece has recognized the important role of LM in improving industrial performance. Indeed, a study conducted by Salonitis and Tsinopoulos (2016) focused on the assessment of LM implementation and the impact of this change on the organization. Their objective was to determine the level of LM understanding, and identify barriers and success factors to implement an effective Lean process.

In SMEs, quality and production departments are more interested in the Lean approach than other company components. In Italy, Rauch et al. (2017) reviewed the application of Lean in the R\&D departments of SMEs; their survey of 54 SMEs showed that the implementation of Lean had high potential for improvement and optimization in product development.

In Malaysia, SMEs represent $96 \%$ of all enterprises, produce $30.7 \%$ of total industrial output and generate $26.3 \%$ of total added value (Albliwi et al., 2014). Malaysia took the initiative to benefit from LM and started a program in 2006 within the scope of the Malaysia-Japan Motor Cooperation (MAJAICO). The program aimed to improve the automotive spare part manufacturing sector by producing higher value-added products, and to improve production capacity and competitiveness by the means of Lean production systems (Mamat et al., 2015).

The Lean concept has become well known around the world. For instance, in Morocco the INMAA (Moroccan Initiative for Improvement) program was initiated in 2011 by the Moroccan Ministry for Industry Trade and New Technologies and Maroc-PME. The mission of the INMAA program is to deploy the principles of LM in the Moroccan industrial fabric, particularly amongst SMEs and very small businesses (VSBs). In 2015, an assessment of the Lean maturity level in Moroccan SMEs was made based on a survey of 18 companies that had been involved in the INMAA program. Overall, this showed that most SMEs were in the process of integrating Lean principles (Fakkous et al., 2015).

Table 2 reviews several studies addressing Lean manufacturing within SMEs in several countries. The methodology used, research objectives and main results of selected articles are outlined in the table.

\section{APPROACHES TO THE IMPLEMENTATION OF LEAN IN SME}

Shingo, an engineer at the Toyota company, was the first to suggest a roadmap for Lean implementation. In fact, he presented the first actions that should be undertaken during the first year of Lean transformation. He identified fifteen Lean tools and techniques to be implemented, such as SMED, Poke Yoke and Kanban. In addition, Kowalski (1996) and Beck (1999) proposed a 10-step Lean implementation model. A comparison of the two approaches shows that Kowalski's model focuses more on efficient work system development and task standardization. On the other hand, Beck's model concentrates on production resource design and implementation (AlManei et al., 2017). Hilbert (1998) has also suggested a two-phase model (see Table 3). Most of steps in this model go far beyond the operational aspect and focus more on the social and cultural.

Anvari et al. (2011) analyzed the Lean implementation approaches presented in the literature between 1996 and 2001, and highlighted the main similarities present. According to their study, three major steps could be identified when implementing a Lean approach: preparation, design and implementation. The different steps of this approach are presented in Table 3. They also suggested a dynamic roadmap model for Lean implementation, taking into account economic data volatility and environment variability. 
Table 2 Research articles addressing Lean manufacturing in SMEs

\begin{tabular}{|c|c|c|c|c|}
\hline Authors & $\begin{array}{c}\text { Investigated } \\
\text { Country }\end{array}$ & Methodology & Research objective & Main results \\
\hline $\begin{array}{l}\text { Rose et al. } \\
(2017)\end{array}$ & Malaysia & $\begin{array}{l}\text { Case studies (Six } \\
\text { SMEs and four large } \\
\text { companies). }\end{array}$ & $\begin{array}{l}\text { - Explore preparations } \\
\text { for Lean } \\
\text { implementation. } \\
\text { - Investigate the } \\
\text { benefits and barriers } \\
\text { of LM deployment. }\end{array}$ & $\begin{array}{l}\text { - A Lean project begins by } \\
\text { constituting the Steering } \\
\text { Committee. } \\
\text { - Implementation of } 5 \mathrm{~S} \text { is the } \\
\text { easiest of the Lean practices. } \\
\text { - All companies started } \\
\text { implementing LM on the } \\
\text { production line that has most } \\
\text { waste. }\end{array}$ \\
\hline $\begin{array}{l}\text { Ferreira et } \\
\text { al. }(2016)\end{array}$ & Brazil & $\begin{array}{l}\text { - Literature review. } \\
\text { - Semi-directed } \\
\text { interviews and } \\
\text { visits. } \\
\text { - Case study of a } \\
\text { bakery. }\end{array}$ & $\begin{array}{l}\text { Lean implementation } \\
\text { in micro and small } \\
\text { bakery companies in } \\
\text { Brazil based on the } \\
\text { Wilson model. }\end{array}$ & $\begin{array}{l}\text { The implementation approach } \\
\text { used } \\
\text { - VSM (Value Stream } \\
\text { Mapping) } \\
\text { - 5S } \\
\text { - Kaizen } \\
\text { - Improvement actions } \\
\text { - Lean assessment }\end{array}$ \\
\hline $\begin{array}{l}\text { Matt and } \\
\text { Rauch } \\
(2013)\end{array}$ & Italy & $\begin{array}{l}\text { - Interviews with } 10 \\
\text { small businesses } \\
\text { (10-49 employees). } \\
\text { - Practical case study } \\
\text { of a company of } 25 \\
\text { employees working } \\
\text { in furniture } \\
\text { manufacturing. }\end{array}$ & $\begin{array}{l}\text { Analyze the current } \\
\text { situation of the } \\
\text { deployment and } \\
\text { implementation of LM } \\
\text { in small businesses. }\end{array}$ & $\begin{array}{l}\text { - Most small businesses } \\
\text { consider that implementing } \\
\text { Lean is expensive and time- } \\
\text { consuming. } \\
\text { - Lean is less known amongst } \\
\text { most small businesses. } \\
\text { Sometimes, these companies } \\
\text { put in place LM practices } \\
\text { without realizing that they } \\
\text { are LM. }\end{array}$ \\
\hline $\begin{array}{l}\text { Ulewicz } \\
\text { and } \\
\text { Kucęba } \\
\text { (2016) }\end{array}$ & Poland & Questionnaire survey. & $\begin{array}{l}\text { Present the obstacles } \\
\text { faced by SMEs when } \\
\text { implementing the Lean } \\
\text { concept. }\end{array}$ & $\begin{array}{l}\text { Lean barriers: lack of } \\
\text { knowledge, poor understanding } \\
\text { of Lean, lack of support, lack } \\
\text { of preparation, limited financial } \\
\text { resources, SMEs are not } \\
\text { sufficiently convinced by the } \\
\text { benefits of Lean. }\end{array}$ \\
\hline $\begin{array}{l}\text { Antosz and } \\
\text { Stadnicka } \\
(2017)\end{array}$ & Poland & $\begin{array}{l}\text { - Case study: } \\
\text { Questionnaire } \\
\text { survey of } 49 \\
\text { companies ( } 53 \% \\
\text { medium and } 14 \% \\
\text { micro). }\end{array}$ & $\begin{array}{l}\text { - Investigation of LM } \\
\text { in SMEs. }\end{array}$ & $\begin{array}{l}\text { The sample studied shows that: } \\
\text { - } 94 \% \text { of companies } \\
\text { confirmed that waste } \\
\text { elimination is their main } \\
\text { objective behind } \\
\text { implementing LM. } \\
\text { - LM techniques that were } \\
\text { applied (in decreasing } \\
\text { order) } 25 \% 5 \mathrm{~S}, 20 \% \text { "5 } \\
\text { why", } 16 \% \text { SMED, } 16 \% \\
\text { group work, } 12 \% \\
\text { standardization, } 12 \% \mathrm{TPM} \text {. }\end{array}$ \\
\hline
\end{tabular}

Belhadi et al. (2016) developed an effective roadmap that included all the prerequisites (processes, tools, success factors) required to implement an appropriate Lean approach in SME and took into account SME characteristics (Table 3), as it was developed based on their own experience. 
Table 3 presents a comparison between the three suggested frameworks; from it we can conclude that there are several points in common between them. However, the literature does not claim that there is one standard process for Lean implementation that suits all organizations.

Table 3 Comparison of the main LM implementation approaches studied in the literature

\begin{tabular}{|c|c|c|}
\hline Anvari et al. (2011) & Belhadi et al. (2016) & Hilbert (1998) \\
\hline Preparation & Pre-implementation & Step 1 \\
\hline $\begin{array}{l}\text { - Assess the strategic planning } \\
\text { gaps. } \\
\text { - Understand the waste. } \\
\text { - Set up goals. } \\
\text { - Obtainthe right organizational } \\
\text { structure. } \\
\text { - Identify global change factors. } \\
\text { - Create a lean team. } \\
\text { - Train staff about lean principles. } \\
\text { - Involve customers and suppliers. } \\
\text { - Recognize the need for change. }\end{array}$ & $\begin{array}{l}\text { - Devise a lean policy/establish } \\
\text { lean objectives. } \\
\text { - Create a lean team. } \\
\text { - Train the lean team. } \\
\text { - Define the initial scope for } \\
\text { implementing LM. } \\
\text { - Deploy the master plan. } \\
\text { - Define and evaluate relevant } \\
\text { Lean indicators. }\end{array}$ & $\begin{array}{l}\text { - } \text { Nominate a lean team. } \\
\text { - Establish a shared vision. among all } \\
\text { stakeholders. } \\
\text { - } \text { Assess the effort needed for change. } \\
\text { - Ensure the current system is stable } \\
\text { enough. } \\
\text { - Define the appropriate policy to } \\
\text { incorporate lean practices. } \\
\text { - Create a design process for } \\
\text { "leanness". } \\
\text { - Provide alternatives and solutions to } \\
\text { resolve potential conflicts. }\end{array}$ \\
\hline Design & Implementation (execution) & Step 2 \\
\hline $\begin{array}{l}\text { - Map thevalue stream. } \\
\text { - Identify opportunities for } \\
\text { improvement. } \\
\text { - Plan the necessary changes. } \\
\text { - Identify relevant indicators to } \\
\text { measure performance. } \\
\text { - Create a feedback mechanism. }\end{array}$ & $\begin{array}{l}\text { - Upgrade staff and } \\
\text { workstations. } \\
\text { - Ensure that lean culture is } \\
\text { deployed. } \\
\text { - Model and analyze the current } \\
\text { situation. } \\
\text { - Identify opportunities for } \\
\text { improvement. } \\
\text { - Implement pilot projects. }\end{array}$ & $\begin{array}{l}\text { - Build a shared vision. } \\
\text { - Design and plan changes. } \\
\text { - Handle changes. } \\
\text { - Assure continuous improvement. }\end{array}$ \\
\hline Implementation & Generalization & ------- \\
\hline $\begin{array}{l}\text { - Start with a pilot project. } \\
\text { - Launch the subsequent } \\
\text { implementation projects. } \\
\text { - Assess and maintain changes. } \\
\text { - Change systems and } \\
\text { philosophies. } \\
\text { - Sell the benefits of thinking } \\
\text { "Lean". } \\
\text { - Pursue perfection. } \\
\text { - Extend the scope of the Lean } \\
\text { process. }\end{array}$ & $\begin{array}{l}\text { - Follow-up the results. } \\
\text { - Ensure that Lean goals are } \\
\text { accomplished. } \\
\text { - Capitalize and standardize } \\
\text { lean practices. } \\
\text { - Generalize best practices. } \\
\text { - Extend the Lean perimeter. }\end{array}$ & \\
\hline
\end{tabular}

\section{DISCUSSION AND CONCLUSION}

Various studies related to Lean manufacturing in SMEs have been conducted, focusing on, for example, Lean advantages, implementation steps, key success factors, implementation barriers, and level of maturity. Lean has proven its effectiveness through many initiatives discussed in the literature. However, these initiatives are generally related to the experience of large companies and SMEs and do not take into account the specific context of very small businesses (VSBs).

VSBs have become the focus of scientific study in recent years, as they play an increasingly important economic and social role and are generally the nerve center of the economy (Matt \& Rauch, 2013). Despite the multitude of Lean implementation frameworks presented in the literature, VSBs are still struggling to implement LM in their organizations (Doolen \& Hacker, 2005; Matt \& Rauch, 2013; Dora et al., 2014; Rymaszewska, 2014; Zhou, 2016; Antosz \& Stadnicka, 2017). Indeed, Lean implementation is not a simple process that only consists of 
copying roadmaps from large and medium companies. The review of the existing key Lean implementation frameworks has revealed the main gaps in the literature and emphasized the lack of an appropriate framework for very small businesses.

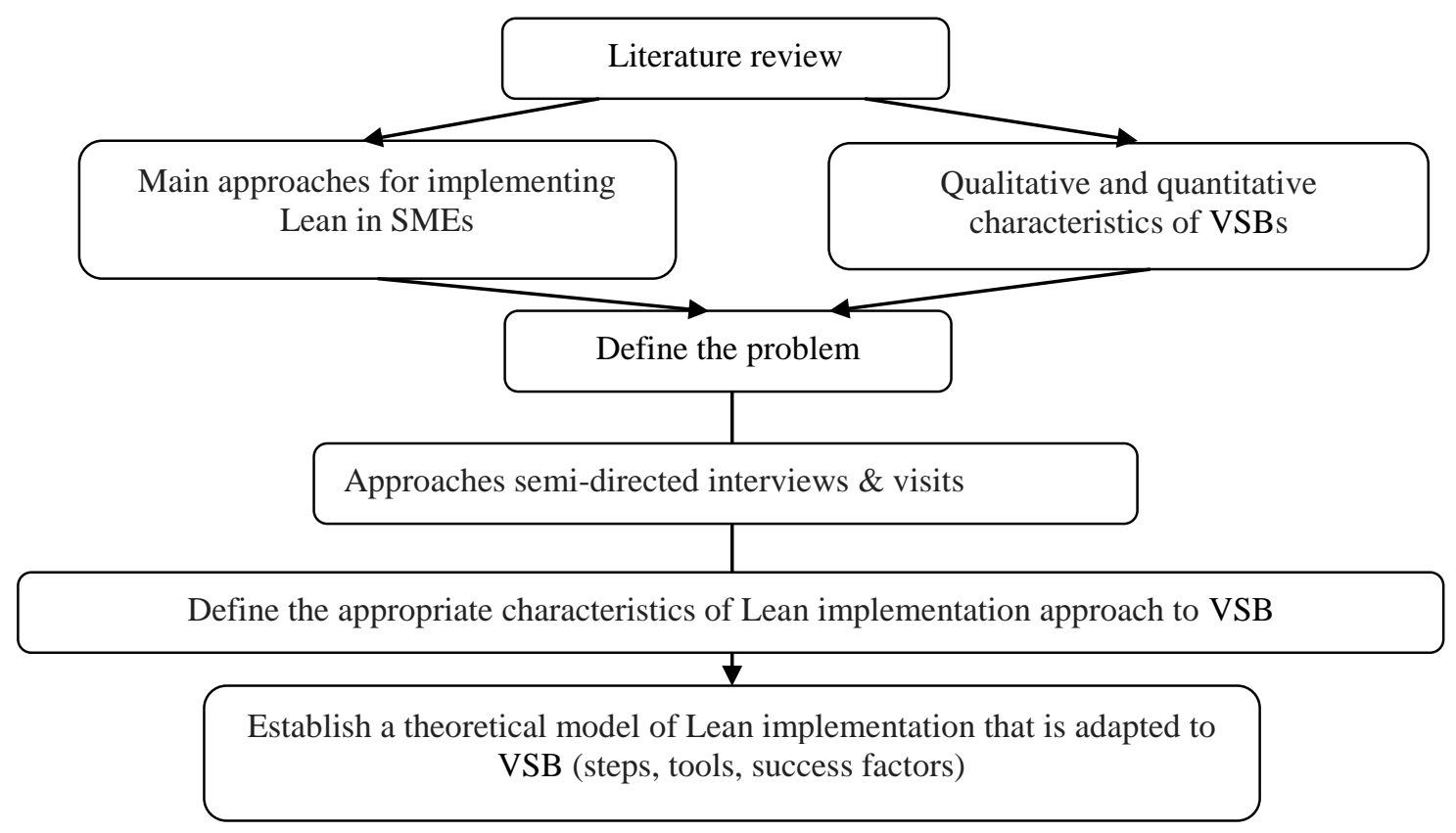

Figure 3 Proposed approach to developing a new Lean implementation framework suitable for very small firms.

For this reason, we suggest an approach to converting the use of Lean by SMEs to the needs of VSBs (Figure 3). It is necessary to start by exploring the existing Lean approaches and examining the main Lean implementation frameworks.

We propose the following approach:

Conduct a literature review to collect Lean implementation approaches and successful initiatives in SMEs. The goal is to juxtapose these steps with developing a new framework, which is convenient, effective and especially suitable for specific VSB features. The implementation framework should contain all the items (processes, tools, success factors) needed to implement Lean in very small businesses.

- Put together all the quantitative and qualitative features related to VSBs in order to design a Lean approach more suitable to their context.

- Conduct an investigation by means of semi-structured interviews and visits to VSEs who have experienced the implementation of Lean to discover the approach taken, the difficulties encountered and the success factors of their experiences.

- Collect and analyze relevant data in order to define the characteristics of the future Lean approach intended for small businesses.

- Establish a theoretic model of Lean implementation adapted to VSB (steps, tools, success factors).

One important limitation of this study is the lack of previous research on the topic. This explains why the proposed approach (Figure 3) is based on Lean manufacturing in SMEs.

Further research should be conducted to identify specific characteristics of very small enterprises to develop an implementation strategy adapted to these companies' requirements. Moreover, 
there is an urgent need to conduct an exploratory study of different manufacturing companies in order to assess their level of readiness to implement Lean manufacturing.

\section{ACKNOWLEDGEMENT}

The authors acknowledge the Laboratory of Mechanics, Production and Industrial Engineering, Higher National School of Electricity and Mechanics Casablanca-Morocco, for the provision of research facilities. The authors would also like to thank the editor and anonymous reviewers for their useful suggestions.

\section{REFERENCES}

Albliwi, S., Antony, J., Abdul Halim Lim, S., van der Wiele, T., 2014. Critical Failure Factors of Lean Six Sigma: A Systematic Literature Review. International Journal of Quality \& Reliability Management, Volume 31(9), pp. 1012-1030

AlManei, M., Salonitis, K., Xu, Y., 2017. Lean Implementation Frameworks: The Challenges for SMEs. Procedia CIRP, Volume 63, pp. 750-755

Antosz, K., Stadnicka, D., 2017. Lean Philosophy Implementation in SMEs - Study Results. Procedia Engineering, Volume 182, pp. 25-32

Anvari, A., Zulkifli, N., Yusuff, R.M., Hojjati, S.M.H., Seyed, M., Ismail, Y., 2011. A Proposed Dynamic Model for a Lean Roadmap. African Journal of Business Management, Volume 5(16), pp. 6727-6737

Baglin, G., Capraro, M., 1999. L'Entreprise Lean Production ou la PME compétitive par l'action collective (The Lean Production Company or the Competitive SME through Collective Action). Presses Universitaires de Lyon

Bajjou, M.S., Chafi, A., 2018a. Towards Implementing Lean Construction in the Moroccan Construction Industry: Survey Study. In: Proceedings of the 2018 International Conference on Optimization and Applications, ICOA 2018. IEEE

Bajjou, M.S., Chafi, A., 2018b. Lean Construction Implementation in the Moroccan Construction Industry: Awareness, Benefits and Barrier. Journal of Engineering, Design and Technology, Volume 16(4), pp. 533-556

Bajjou, M.S., Chafi, A., 2018c. Barriers of Lean Construction Implementation in the Moroccan Construction Industry. AIP Conference Proceedings, Volume 1952(1), p. 020056. AIP Publishing

Bajjou, M.S., Chafi, A., 2018d. Empirical Study of Schedule Delay in Moroccan Construction Projects. International Journal of Construction Management, Volume 0(0), pp. 1-8

Bajjou, M.S., Chafi, A., Ennadi, A. 2019. Development of a Conceptual Framework of Lean Construction Principles: An Input-Output Model. Journal of Advanced Manufacturing Systems, Volume 18(1), pp. 1-34

Bakås, O., Govaert, T., Van Landeghem, H., 2011. Challenges and Success Factors for Implementation of Lean Manufacturing in European SMES In: 13th International conference on the modern information technology in the innovation processes of the industrial enterprise (MITIP 2011) Volume 1

Beck, K., 1999. Extreme Programming Explained: Embracechange. Addison-wesley Professional

Belhadi, A., Touriki, F.E., Fezazi, S.E., 2016. A Framework for Effective Implementation of Lean Production in Small and Medium-sized Enterprises. Journal of Industrial Engineering and Management, Volume 9(3), pp. 786-810

CDVM (Conseil déontologique des valeursmobilières), 2011. Financement des PME au Maroc.

Demeter, K., Matyusz, Z., 2011. The Impact of Lean Practices on Inventory Turnover. International Journal of Production Economics, Volume 133(1), pp. 154-163 
Dora, M., Van Goubergen, D., Kumar, M., Molnar, A., Gellynck, X., 2014. Application of Lean Practices in Small and Medium-sized Food Enterprises. British Food Journal, Volume 116(1), pp. 125-141

Doolen, T.L., Hacker, M.E., 2005. A Review of Lean Assessment in Organizations: An Exploratory Study of Lean Practices by Electronics Manufacturers. Journal of Manufacturing Systems, Volume 24(1), pp. 55-67

Drew, J., McCallum, B., Roggenhofer, S., de Angéli, G., 2004. Objectif Lean: Réussir l'entreprise au plus juste: enjeux techniques et culturels (Lean Objective: To Make the Company as Successful as Possible: Technical and Cultural Issues). Broché

Fakkous, M., Ennadi, A., Chafi, A., 2015. Etude de niveau de maturité Lean de la PME marocaine "Lean maturity study of the Moroccan SME". In: Conference Proceeding

Ferreira, W.P., Silva, A.M., Zampini, E.F., Pire, C.O., 2016. Lean Manufacturing Micro and Small Enterprises (MSE): A Study in the Bakery Segment. In: XXXVI National Meeting Of Production Engineering Contributions of Production Engineering for Best Management and Modernization Practices in Brazil

Gandhi, N.S., Thanki, S.J., Thakkar, J.J., 2018. Ranking of Drivers for Integrated Lean-green Manufacturing for Indian Manufacturing SMEs. Journal of Cleaner Production, Volume 171, pp. 675-689

Garre, P., Nikhil Bharadwaj, V.V.S., Shiva Shashank, P., Harish, M., Sai Dheeraj, M., 2017. Applying Lean in Aerospace Manufacturing. Materials Today Proceedings, Volume 4(8), pp. 8439-8446

Hilbert, H., 1998. Effective Coordination of Technical and Social Component during the Design and Launch of a New Lean Manufacturing Work System. Massachusetts Institute of Technology

Kilpatrick, J., 2003. Lean Principles. Utah Manufacturing. Extention, Partnership, pp. 1-5

Kowalski, J.S, 1996. An Evaluation of the Design of Manufacturing Measurable for the Ford Production. Master thesis, MIT Camb

Liker, J., 2004. The Toyota Way: 14 Management Principles from the World's Greatest Manufacturer. Mc Graw-Hill Education

Lyonnet, B., 2010. Amélioration de la performance industrielle: vers un système de production Lean adapté auxentreprises du pole de compétitivité Arve Industrie Haute-Savoie MontBlanc (Improvement of Industrial Performance: Towards a Lean Production System Adapted to the Companies of the Arve Industries Haute-Savoie Mont-Blanc Competitiveness Cluster). Université de Savoie

Mamat, R., Md Deros, B., Ab Rahman, M.N., Khalil Omar, M., Abdullah, S., 2015. Soft Lean Practices for Successful Production System Implementation in Malaysia Automotive SMEs: A Proposed Framework. Jurnal Teknologi, Volume 77(27), pp. 141-150

Matt, D.T., Rauch, E., 2013. Implementation of Lean Production in Small Sized Enterprises. Procedia CIRP, Volume12, pp. 420-425

Muller, P., Julius, J., Herr, D., Koch, L., Peycheva, V., McKiernan, S., 2017. Annual Report on European SMEs 2016/2017. European Commission

Narayanamurthy, G., Gurumurthy, A., Subramanian, N., Moser, R., 2018. Assessing the Readiness to Implement Lean in Healthcare Institutions - A Case Study. International Journal of Production Economics, Volume 197, pp. 123-142

Prakash, N., Prasad, C., 2014. Lean Practices in Small and Medium Manufacturing EnterprisesA Structured Literature Review. Journal of Basic and Applied Engineering Research, Volume 1(4), pp. 78-84

Rauch, E., Dallasega, P., Matt, D.T., 2017. Critical Factors for Introducing Lean Product Development to Small and Medium Sized Enterprises in Italy. Procedia CIRP, Volume 60, pp. 362-367 
Rose, Ab Rashid, M.F.F., Mohamed, N.N., Ahmad, H., 2017. Similarities of Lean Manufacturing Approaches Implementation in SMEs Towards the Success: Case Study in the Automotive Component Industry. In: MATEC Web of Conferences. EDP Sciences, Volume 87, pp. 02024

Rymaszewska, A,D., 2014. The Challenges of Lean Manufacturing Implementation in SMEs. Benchmarking: An International Journal, Volume 21, pp. 987-1002

Saleh, A.S., Ndubisi, N.O., 2006. SME Development in Malaysia: Domestic and Global Challenges. University of Wollongong

Salonitis, K., Tsinopoulos, C., 2016. Drivers and Barriers of Lean Implementation in the Greek Manufacturing Sector. Procedia CIRP, Volume 57, pp. 189-194

Saurin, T.A., Ferreira, C.F., 2009. The Impacts of Lean Production on Working Conditions: A Case Study of a Harvester Assembly Line in Brazil. International Journal of Industrial Ergonomics, Volume 39(2), pp. 403-412

Treville, S., Antonakis, J., 2006. Could Lean Production Job Design Be Intrinsically Motivating? Contextual, Configurational, and Levels-of-Analysis Issues. Journal of Operations Management, Volume 24(2), pp. 99- 123

Ulewicz, R., Kucęba, R., 2016. Identification of Problems of Implementation of Lean Concept in the SME Sector. Ekon. Zarzadzanie, Volume 8(1), pp. 19-25

Verma, N., Sharma, V., 2017. Sustainable Competitive Advantage by Implementing Lean Manufacturing "A Case Study for Indian SMEs". Materials Today: Proceedings, Volume 4(8), pp. 9210-9217

Womack J., Jones D., 2005. Systéme Lean: Penser l'entreprise au plus juste (System Lean: Thinking the Company at the Fairest), 2ème édition. ed. Village Mondial, Paris

Womack, J. P., Jones, D.T., Roos, D., 1990. The Machine that Changed the World. Simon and Schuster

Zhou, B., 2016. Lean Principles, Practices, and Impacts: A Study on Small and Medium-sized Enterprises (SMEs). Annals of Operations Research, Volume 241(1-2), pp. 457-474 